\title{
Environmental impacts and nutrient recycling on pastures grazed by cattle
}

\author{
Vendramini, J.M.B., Silveira, M.L.A., Dubeux Jr., J.C.B. \& Sollenberger L.E.
}

\begin{abstract}
Grasslands are being replaced by urbanization and more profitable agricultural activities around the world. Producers may be faced with land constraints and need to consider intensification of the remaining grasslands as a means of maintaining overall production on a decreasing land resource. However, intensification of the grazing system is usually associated with greater nutrient inputs, including those from commercial fertilizers and supplement fed to animals. Excessive loading of nutrients in intensive grazing systems via fertilizer and animal wastes can cause nutrient buildup in the soil and subsequent water quality problems. Surface runoff and leaching of nutrients are the two major process affecting water quality. Nitrogen and P represent major nutrient concerns as related to water quality. Increased nitrate concentrations render groundwater unsuitable for drinking and can cause serious health issues for humans. Excessive $\mathrm{N}$ and $\mathrm{P}$ concentrations may contribute to eutrophication of streams and lakes. Maximizing efficiency of nutrient recycling through the soil-forage-animal system minimizes off-site nutrient transport and decreases production costs by reducing the quantity of commercial fertilizer needed. Management strategies to reduce soil and water contamination include refining the balance of nutrient inputs from feeds and fertilizers as well as accounting for the nutrients recycled through the decomposition of plant litter and animal wastes. Current interest in the development and adoption of efficient and sustainable agriculture systems has led forage researchers to amplify the scope of grasslands research by increasing multidisciplinary efforts. There is an increased interest in quantifying the impacts of forage-animal management strategies on the environment, with the goal of developing economically viable best management practices that result in optimum forage production and profitability, while protecting the environment. Furthermore, these best management practices will supply reliable information for future environmental policies that may be adopted by governmental agencies.
\end{abstract}

Key Words: cattle, forage, grassland, nutrient cycling, water quality

\section{Introduction}

Grassland covers approximately $51 \%$ of the land earth's surface (Pearson and Ison, 1997) and are found mainly in Africa, Australia, South America, and North America (World Resource Institute, 2001). The majority of these areas are extensively grazed by livestock. The grazing systems used in different regions reflect the climatic and socio-economic aspects of the region because biological efficiencies within the system seldom are the sole driving force that gives rise to a particular grazing system (Burns et al., 2004). Rapid urbanization, higher land values, and the alternative of planting more profitable crops are leading to reduction of grassland areas. The alternative uses of grasslands may force producers to manage pastures more intensively. According to Lal and Stewart (1994), intensive agricultural practices may involve bringing new land under agriculture or intensively farming existing land. Both systems can have drastic adverse impact on consumptive use and quality of water resources (Lal and Stewart, 1994). From the planted pastures perspective, intensification is commonly associated with greater fertilization and animal supplementation for increasing forage and animal production. Traditionally, the decision to intensify a grazing system has been subject primarily to the economics of the adopted practice. Presently, an increased public awareness of the role of such practices in nonpoint source pollution has elevated the importance of environmental impact of current and proposed agricultural management practices.

The objectives of this paper are:

1) to describe the major sources of inputs to planted pastures, 
2) to relate those input sources with environmental quality, and

3) to review the importance of nutrient cycling on grasslands.

\section{Major inputs to intensively grazed pastures}

\subsection{Mineral fertilization}

Profitable crop production depends on many factors and except for sunlight and water, soil fertility most frequently limits crop yields (Sharpley and Halvorson, 1994). In general, grasslands are located on marginal areas usually associated with low soil fertility. The combination of low soil nutrients, efficient nutrient extraction capability, and high total yield potential creates conditions favorable for obtaining large yields responses from added plant nutrients (Matthews et al., 2004). According to Teitzel and Wilson (1991), pasture productivity is always a function of grazing management and fertilization, regardless of initial soil fertility status.

Macro and micro nutrients are essential for plant development and most of them when applied in excess may become an environmental concern. However, $\mathrm{N}$ and $\mathrm{P}$ fertilization has been the main focus of environmental regulatory programs primarily because of the larger amount of these nutrients applied on agriculture lands and their significant potential for negative environmental consequences.

\subsubsection{Nitrogen}

Nitrogen is the most limiting nutrient for plant growth in most of the world's agricultural soils, hence, crop production worldwide relies heavily on inputs of $\mathrm{N}$ from organic or inorganic sources (Muchovej and Rechcigl, 1994). The ultimate source of $\mathrm{N}$ is inert dinitrogen gas, which compromise approximately $78 \%$ of the earth's atmosphere. Dinitrogen is converted to forms usable by higher plants and animals by the combination with $\mathrm{H}_{2}$ or $\mathrm{O}_{2}$ in a number of processes: in biological $\mathrm{N}_{2}$ fixation by bacteria, in atmospheric discharges, and industrially, as $\mathrm{NH}_{3}$, $\mathrm{NO}_{3}$ or cyanamide for the manufacture of commercial fertilizers (Muchovej \& Rechcigl, 1994). $\mathrm{N}$ inputs in the soil are in the forms of aerial deposition, biological $\mathrm{N}_{2}$ fixation, animal and green manures, and synthetic $\mathrm{N}$ fertilizers. $\mathrm{N}$ exists in the soil as $\mathrm{NO}_{2}, \mathrm{NO}_{3}$, or $\mathrm{NH}_{4}$, or in organic form within the soil organic matter fraction. The fate of $\mathrm{N}$ fertilizers in the soil-plant system is governed by several physical, chemical, and biological factors within a specific environment (Boswell et $a l .$, 1985). It is well documented in the literature that $\mathrm{N}$ fertilization usually results in increased production on grasslands (Overman et al., 1992; Prine and Burton, 1956; Vicente-Chandler et al., 1974). Increased $\mathrm{N}$ fertilizer utilization has not always equated to increased efficiency of use. As farmers and those advising farmers learned to use new fertilizer material alone or in combination with organic $\mathrm{N}$ sources, new application equipment, and new cropping systems, they often did so without a real understanding of the potential environment impacts involved (Pierzynski et al., 2005). Grassland systems recover between 50 and $65 \%$ of the fertilizer $\mathrm{N}$ as harvested yield in the year of application (Schepers and Mosier, 1991). In grazed pastures fertilized with 200 to $250 \mathrm{~kg} \mathrm{~N}$ $\mathrm{ha}^{-1} \mathrm{yr}^{-1}$ as $\left(\mathrm{NH}_{2}\right)_{2} \mathrm{CO}$, nearly a third of the $\mathrm{N}$ input was retained in the soil organic matter $(25 \%)$ and root system (2-5\%). The remainder was lost via ammonia volatilization from the soil following application (20\%), ammonia volatilization from urine patches (20-30\%), denitrification (6-12\%), animal liveweight gain (7-9\%) or milk production (14-18\%), and leaching or unaccounted losses such as excretion off pasture (20-50\%) (Kimura and Kurashima, 1991; Whitehead, 2000; Matthews et al., 2001) cited by (Matthews et al., 2004). In a grass system, the amount of $\mathrm{N}$ lost by leaching depends on: the form and amount of soluble $\mathrm{N}$ present or added; amount and time of rainfall; infiltration and percolation rate of water; water holding capacity; evapotranspiration, rate of removal of $\mathrm{N}$ by the crop and whether the $\mathrm{N}$ is leached below the root zone (Allison, 1961).

\subsubsection{Phosphorus}

Profitable crop production depends on many factors, including a sound $\mathrm{P}$-management program. Most of the Earth's $\mathrm{P}$ found is in terrestrial soils and in the sediments of fresh waters, estuaries, and oceans. Worldwide, soil P deficiency for several crops is common (World Resource Institute, 1987). According to Sharpley and Halvorson (1994), soil testing is the best tool 
available to assess the need for $\mathrm{P}$ fertilization. Fertilizer $\mathrm{P}$ management varies with location and site-specific conditions, such as initial soil test $\mathrm{P}$ level, soil type, soil $\mathrm{pH}$, available application equipment, crop rotation and tillage system. Accurately assessing soil P status and the quantity of $\mathrm{P}$ fertilizer required to alleviate $\mathrm{P}$ deficiency is necessary if maximum economic yields are to be obtained (Sharpley \& Halvorson, 1994).

Phosphorus is one of the most immobile of the plant nutrients in soil due to adsorption and precipitation reactions involving $\mathrm{Fe}$ and $\mathrm{Al}$ in acid soils and $\mathrm{Ca}$ in alkaline soils (Whitehead, 2000). With the application of $\mathrm{P}$, available soil $\mathrm{P}$ concentration increases. This increase is a function of physical and chemical soil properties (Peterson $\&$ Krueger, 1980). The portion of fertilizer $P$ remaining as available $\mathrm{P} 6$ months after application, decreased as clay, organic $\mathrm{C}, \mathrm{Fe}, \mathrm{Al}$, and $\mathrm{CaCO}_{3}$ concentration increased for over 100 widely differing soils (Sharpley and Halvorson, 1994) (Table 1).

Table 1 - Percent fertilizer P available (as $\mathrm{P}$ resin) 6 months after application.

\begin{tabular}{lccc}
\hline \multirow{2}{*}{ Soil Property } & $\begin{array}{c}\text { Number } \\
\text { of soils }\end{array}$ & \multicolumn{2}{c}{$\begin{array}{c}\text { Availability } \\
(\%)\end{array}$} \\
\cline { 3 - 4 } & & Mean & Range \\
\hline Slightly weathered & 80 & 47 & $11-72$ \\
Moderately weathered & 27 & 32 & $6-51$ \\
Highly weathered & 40 & 27 & $14-54$ \\
\hline
\end{tabular}

Adapted from Sharpley and Halvorson (1994).

Plants vary widely in their $\mathrm{P}$ concentrations, with most forages containing from 0.1 to $0.5 \% \mathrm{P}$ (Table 2), much less than the concentration of other major essential elements such as $\mathrm{N}$ and $\mathrm{K}$ (2 $4 \%$ ). Decreased plant absorption associated with repeated application of mineral $\mathrm{P}$ fertilizer has potential to enhance $\mathrm{P}$ losses; however, it is not the major source of $\mathrm{P}$ contamination reported in the literature.

\subsection{Organic Fertilization}

Manures and slurries have traditionally been applied to agricultural lands. The addition of municipal organic wastes to soils is becoming an economically attractive fertilization option and convenient method of disposal. Manures and organic wastes are variable in composition (Table 3 ) and therefore concentration of plant available nutrients is not predictable (Kirchmann, 1994). In addition, the transformations that occur in the organic material during the collection and storage processes may have a significant impact on the nutrient form and concentration. The concentration and forms of $\mathrm{N}$ varies according to the decomposition process, tending to decrease in most situations due to $\mathrm{N}$ volatilization. However, the concentration of non-volatile elements such as $\mathrm{P}, \mathrm{K}, \mathrm{Ca}$, and $\mathrm{Mg}$, increases during the decomposition process as the result of microbial carbon respiration (Kirchmann, 1985).

Studies on the availability of $\mathrm{N}$ from organic materials have been a central research focus for agronomists. Kirchmann (1991) presented the N mineralization patterns of nine types of animal manures under different storage conditions (Figure 1). According to Hadas et al., (1983), fertilization with fresh poultry manure resulted in a rapid increase in inorganic $\mathrm{N}$ in soil within 2 weeks after addition, amounting to more than $50 \%$ of the total $\mathrm{N}$ present. The rapid $\mathrm{N}$ mineralization of organic compounds increases the potential $\mathrm{N}$ losses to the environment; however, in studies comparing leaching of $\mathrm{N}$ from organic manures with that from

Table 2 - Phosphorus concentration and removal in the harvested portion of some major agricultural crops.

\begin{tabular}{|c|c|c|c|}
\hline Crop category & $\begin{array}{c}\text { Phosphorus } \\
\text { Concentration }(\%)\end{array}$ & $\begin{array}{c}\text { Crop } \\
\left(\mathrm{Mg} \mathrm{ha}^{-1}\right)\end{array}$ & $\begin{array}{l}\text { Yield Phosphorus } \\
\text { Removal (kg P ha-1) }\end{array}$ \\
\hline \multicolumn{4}{|l|}{ Grains } \\
\hline Corn $^{\mathrm{a}}$ & 0.28 & 10 & 28 \\
\hline Soybeans ${ }^{\mathrm{a}}$ & 0.58 & 3 & 17 \\
\hline \multicolumn{4}{|l|}{ Forages } \\
\hline Alfalfa ${ }^{b}$ & 0.50 & 10 & 50 \\
\hline Bermudagrass $^{\mathrm{c}}$ & 0.40 & 10 & 40 \\
\hline Tall Fescue ${ }^{\mathrm{a}}$ & 0.35 & 9 & 31 \\
\hline
\end{tabular}

Adapted from aPierzynski and Logan (1993), 'banyon and Griffith (1988), and ${ }^{\mathrm{c}}$ Vieira et al. (1999). 
inorganic fertilizers applied at the same total $\mathrm{N}$ amount showed that, $\mathrm{N}$ leaching was lower from organic manure than mineral fertilizer under grazing (Jarvis et al., 1987).

Table 3 - Nutrient concentrations based on dry matter of fresh and anaerobically decomposed animal manure and sewage biosolids.

\begin{tabular}{lccc}
\hline Type of material & $\mathbf{C}(\boldsymbol{\%})$ & $\mathbf{N}(\%)$ & $\mathbf{P}(\%)$ \\
\hline Cattle Feces & & & \\
Fresh & 43.0 & 2.33 & 0.90 \\
$\quad$ Anaerobic & 40.4 & 4.15 & 0.93 \\
Swine Feces & & & \\
$\quad$ Fresh & 44.7 & 3.08 & 2.90 \\
Anaerobic & 44.4 & 4.25 & 1.97 \\
$\quad$ Sewage Biosolids & 32.0 & 4.00 & 2.50 \\
\hline
\end{tabular}

Adapted from Pierzynski et al. (2005).
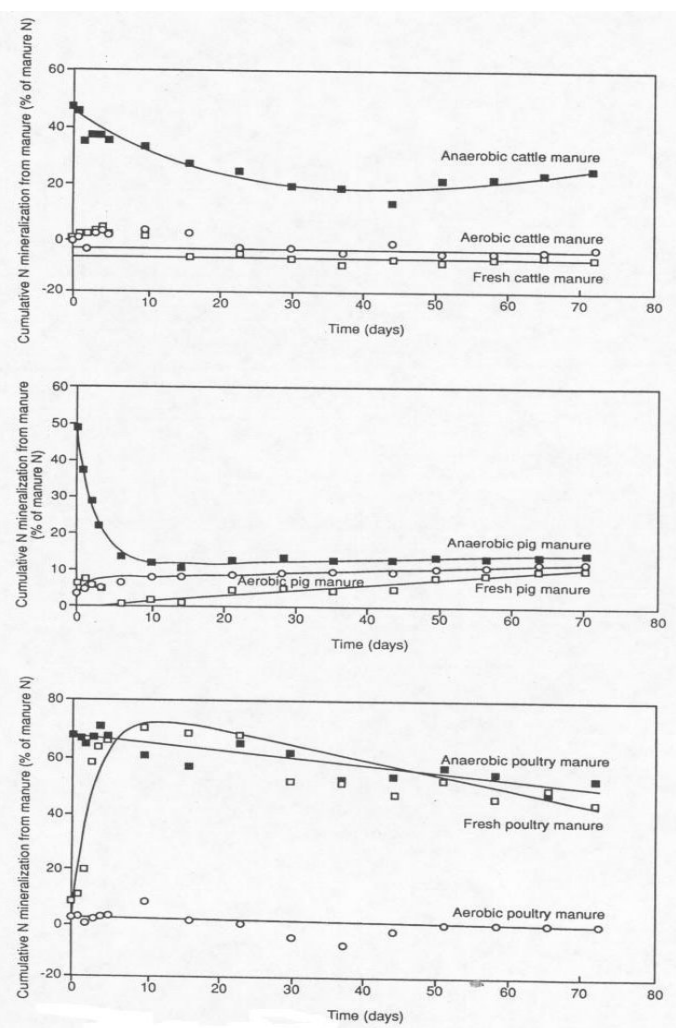

Figure 1 - $\mathrm{N}$ mineralization of manure from three different animal species.

In general, the key to effective use of organic $\mathrm{N}$ sources is an understanding of the factors that influence the extent and rate of conversion of organic $\mathrm{N}$ to forms that are available for plant uptake or for loss to the environment. The availability of $\mathrm{N}$ in organic by-products will be influenced by their composition, a factor that is largely controlled by production and storage practices (Pierzynski et al., 2005).

Organic agricultural and municipal byproducts are often the applied repeatedly to the same soils within a limited geographic area for economic reasons. In addition, manure application rates often have been based on crop $\mathrm{N}$ requirement. Under these scenarios, soil P may buildup to levels of environmental concern. On concentrated animalbased agriculture (feedlot, dairy, swine, and poultry operations), where harvested organic $\mathrm{P}$ (grains, forages, and silage) is transformed into animal manure organic and inorganic $\mathrm{P}$ (as much as $60 \%$ of the $\mathrm{P}$ in some animal manures is inorganic P) (Pierzynski et al., 2005). With time, much of the organic $\mathrm{P}$ added in biosolids and manures is degraded by soil microorganisms and converted to soluble and inorganic forms of $\mathrm{P}$. The increase in soil $\mathrm{P}$ availability is related to the rate of manure application. For four loam soils receiving long-term ( 8 -35 years) poultry or swine manure, available $\mathrm{P}$ concentration of the surface $50 \mathrm{~cm}$ of soil increased an average of $27 \mathrm{~kg} \mathrm{P}$ ha${ }^{1}$ for every $100 \mathrm{~kg} \mathrm{Pha}^{-1}$ of added manure (Sharpley et al., 1991).

\subsection{Supplementation}

Supplementation is an indirect way that nutrients can be brought into grazing lands. The proportion of ingested nutrients utilized by farm animals is relatively small. On average, $80 \%$ of the $\mathrm{N}, 78 \%$ of $\mathrm{P}$, and $95 \%$ of $\mathrm{K}$ present in the fodder is recovered in animal excreta. The composition of excreted animal residues depends on species and age of the animal and type of diet (Kirchmann, 1994).

Energy supplementation to livestock grazing high- $\mathrm{N}$ forages may reduce $\mathrm{N}$ losses through excreta, lowering $\mathrm{N}$ emissions to the environment and increasing $\mathrm{N}$-use efficiency by the animal (Vuuren et al., 1993). Valk \& Hobbelink (1992) reported an increase in $\mathrm{N}$-use efficiency and a $50 \%$ reduction in $\mathrm{N}$ excreted through urine when cows were fed a balanced diet in terms of energy and protein. In contrast, increased $\mathrm{N}$ intake of ruminants beyond their requirements resulted in larger excretion of urine $\mathrm{N}$ (Van Vuuren \& Meijs, 1987).

Phosphorus losses from intensive livestock farms account for as much as $47 \%$ of the P loading to bodies of surface water, depending on the 
watershed (Smith \& Alexander, 2000). These P losses may be reduced significantly by feeding rations that more precisely meet the requirements of animals. A reduction in dietary $\mathrm{P}$ to more closely match the cow's requirement can result in 25 to $30 \%$ less manure $\mathrm{P}$ and a savings of $10-15$ US\$ per cow per year in $\mathrm{P}$ supplementation cost $(\mathrm{Wu}$ et al., 2000).

Although it is well known that $\mathrm{P}$ is an essential and critical nutrient for animal production, management changes can be made to prevent the long-term accumulation of soil $\mathrm{P}$ on dairy farms while improving farm profitability (Rotz et al., 2002).

\section{Nutrient transport and eutrophication}

For decades, soil fertility primarily focused on the agronomic aspects of crop and livestock production. However, because of the growing concerns over accelerated water degradation, current nutrient management programs are based on environmentally sound management practices that result in optimum profitability, while protecting the environment.

Excessive application of fertilizers or animal wastes can result in nutrient buildup in the soil and subsequent transport to surface waters. In most freshwater systems, primary productivity is limited by inadequate levels of nutrients, primarily $\mathrm{N}$ and P. External nutrient inputs from surface runoff and groundwater discharge can dramatically increase $\mathrm{N}$ and $\mathrm{P}$ status of natural waters, stimulating biological productivity and a general degradation of water quality. This phenomenon of nutrient enrichment in aquatic system, also known as eutrophication, has been identified as the major cause of surface water impairment in the USA (USEPA, 1996). Besides the concerns associated with drinking water quality, the process of eutrophication can also affect algae, aquatic plant diversity and productivity, and water use for recreation and fisheries.

Both human and natural factors may affect the trophic status of aquatic systems. Four trophic levels have been identified by limnologists who used as a tool to assess the nutrient levels of fresh water resources. Oligotrophic lakes are very low in nutrients, so few algae grow and the water is very clear. Oligotrophic lakes are biologically less productive lakes and support very few plants and fish. Mesotrophic lakes are moderately productive, with slightly green water. Eutrophic lakes are productive lakes with murkier water, and/ or lots of plants. Hypereutrophic lakes are very high in nutrients and their water is clouded with algae. Hypereutrophic lakes are the most biologically productive lakes, and support large amounts of plants, fish, and other animals.

As agriculture continues to modernize and intensify, public concerns about the impacts of plant nutrients and organic contaminants on environmental quality will increase. Because of the rapid population growth rate in many parts of the world, agriculture and urban societies will increasingly compete for finite water supplies. Protecting water quality while maintaining a profitable agriculture will be a major challenge for the future generations.

\subsection{Nitrogen and the environment}

Nitrogen is unquestionably the most important crop nutrient and yet, the most difficult element to manage. To fully understand the environmental problems associated with $\mathrm{N}$, it is important to recognize the various aspects of $\mathrm{N}$ dynamics in terrestrial ecosystems. Nitrogen is a very dynamic nutrient and can occur in different chemical forms in the soil and atmosphere (Figure 2).

Total $\mathrm{N}$ concentration in the top 15 to $20 \mathrm{~cm}$ of surface soils ranges from 0.01 in desert soils to $2.5 \%$ in peat soils (Prasad \& Power, 1997). The majority of the soil $\mathrm{N}$ occurs in organic forms, such as proteins and amino sugars. A small fraction of soil total $\mathrm{N}$ is found as inorganic forms $\left(\mathrm{NH}_{4}{ }^{+}\right.$and $\mathrm{NO}_{3}^{-}$).

Once $\mathrm{N}$ is mineralized, inorganic $\mathrm{N}$ can be lost via different pathways. For instance, when ammoniacal fertilizers are surface applied, a considerable fraction of the $\mathrm{N}$ can be lost by $\mathrm{NH}_{3}$ volatilization. Especially in soils with relatively high soil $\mathrm{pH}, \mathrm{NH}_{3}$ volatilization, as described in eq. 1 and 2, can be an important pathway for $\mathrm{N}$ losses.

$$
\begin{array}{r}
\mathrm{NH}_{4}{ }^{+}+\mathrm{OH}^{+}=\mathrm{NH}_{3 \text { (Sol.) }}+\mathrm{H}_{2} \mathrm{O} \\
\mathrm{NH}_{3 \text { (Sol. })}=\mathrm{NH}_{3 \text { (gas.) }}
\end{array}
$$

Similarly to $\mathrm{NH}_{3}$ volatilization, under specific conditions $\mathrm{NO}_{3}{ }^{-}$can be reduced to gaseous forms

๑ 2007 Sociedade Brasileira de Zootecnia 


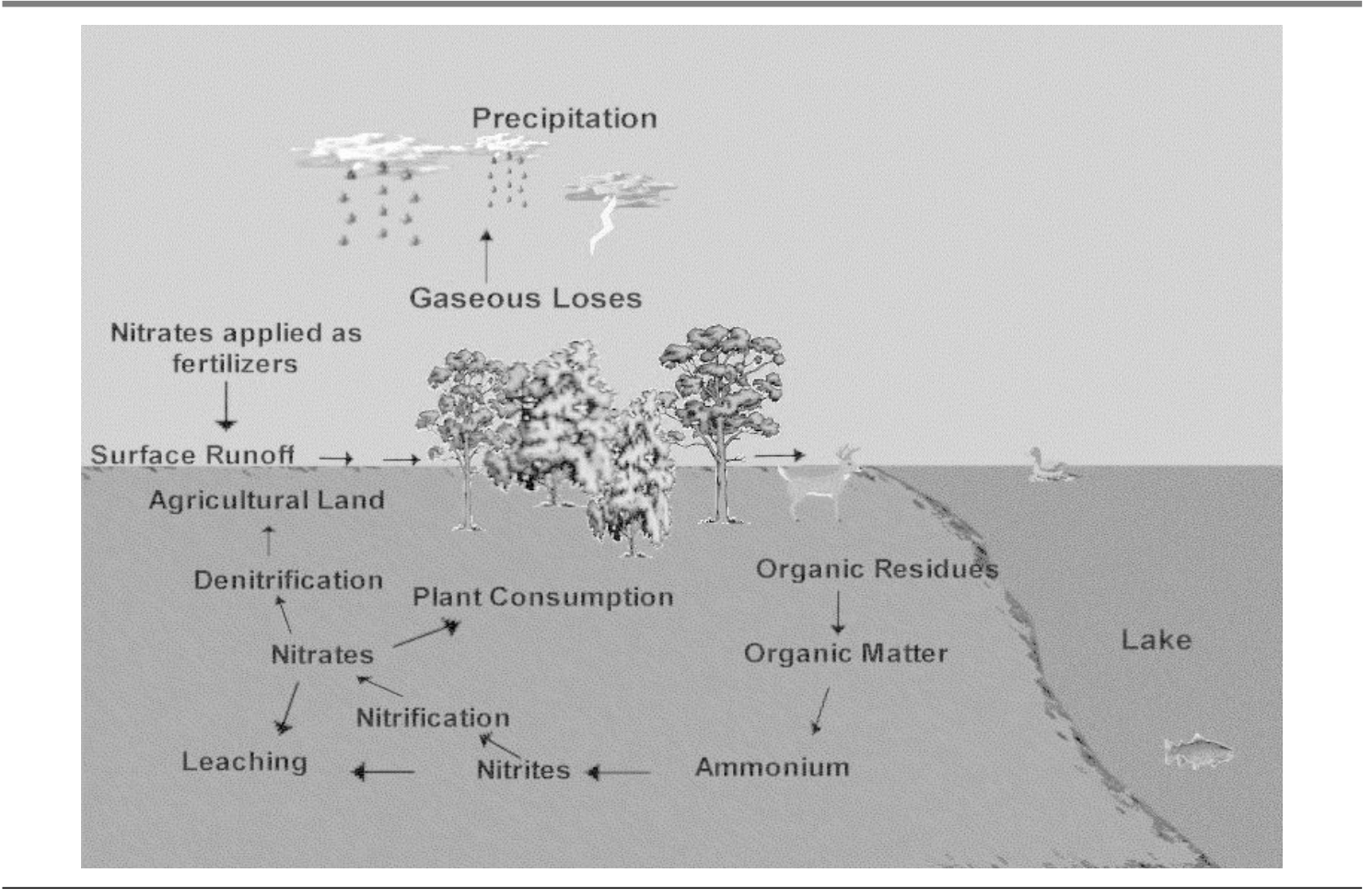

Figure 2 - Nitrogen cycle in terrestrial ecosystems.

of $\mathrm{N}\left(\mathrm{NO}, \mathrm{N}_{2} \mathrm{O}\right.$, and $\left.\mathrm{N}_{2}\right)$. This process, also knows as denitrification, is represented by eq. 3 .

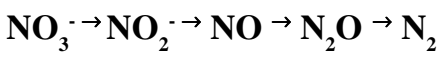

Unlike $\mathrm{NH}_{4}^{+}$that can be retained by soil colloids, $\mathrm{NO}_{3}^{-}$moves easily in the soil profile. Movement of NO3- below the root represents a serious economic and environmental problem for farmers. Extensive research with fertilizer, byproducts and animal manure has been conducted in order to minimize $\mathrm{NO}_{3}{ }^{-}$leaching potential and numerous best management practices have been developed to improve $\mathrm{N}$ efficiency. However, alternatives to minimize $\mathrm{N}$ pollution will likely be site-specific and will depend on soil physical and hydraulic characteristics, as well as the rainfall and irrigation regimens of a specific region.

Controlling $\mathrm{N}$ leaching has become a major issue in the USA because of the growing concerns over increased concentrations of $\mathrm{NO}_{3}^{-}$in drinking water. The USA Environmental Protection Agency established in 1996 the maximum $\mathrm{NO}_{3}$ concentration in drinking water of $10 \mathrm{mg} \mathrm{NO}_{3}-\mathrm{N}$ $\mathrm{L}^{-1}$ (USEPA, 1996). This standard is believed to protect human health and avoid the adverse environmental effects associated with increased $\mathrm{NO}_{3}$ levels in groundwater resources.

\subsection{Phosphorus and the environment}

Unlike $\mathrm{N}$, which constitutes $79 \%$ of the atmosphere, most of earth's $\mathrm{P}$ is found in terrestrial ecosystems. In soils, $\mathrm{P}$ can be found in organic and inorganic forms (Figure 3).

Organic $\mathrm{P}$ is mineralized by soil organismsinto inorganic $\mathrm{P}$ forms, which can be absorbed by plants. The chemical distribution of inorganic forms of $\mathrm{P}$ in soils is dependent on soil $\mathrm{pH}$; however, in general, $\mathrm{H}_{2} \mathrm{PO}_{4}^{-}$is the predominant chemical $\mathrm{P}$ species in agricultural soils. Soil $\mathrm{P}$ is most available for plants at $\mathrm{pH}$ between 6 to 7. In slightly acidic environments ( $\mathrm{pH}$ less than 6), plant-available $\mathrm{P}$ becomes increasingly tied up in iron and aluminum phosphates and crop nutrient deficiency may occur.

Although $\mathrm{P}$ is essential in agriculture for plant and animal growth, environmental concerns over $\mathrm{P}$ movement into water reservoirs has become a major focus of water quality programs. Phosphorus may be transported from agricultural soils into water bodies via surface runoff, subsurface lateral flow, and leaching (Sharpley et $a l .$, 1993). The magnitude of each pathway in terms of $\mathrm{P}$ transport will depend on the soil and landscape characteristics. For instance, in sandy soils with little P-retention capacity, leaching is likely the 


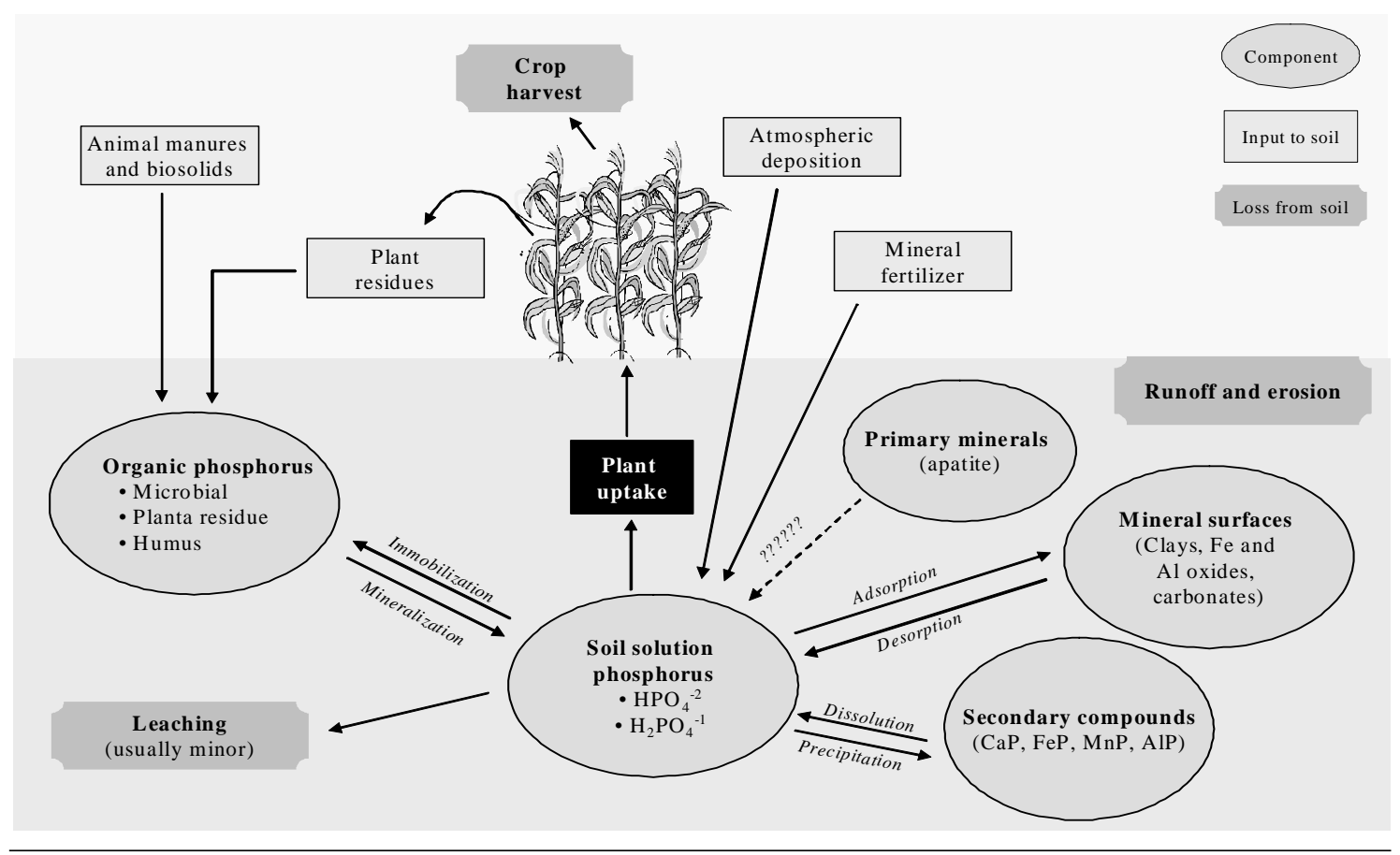

Figure 3 - Phosphorus cycle in terrestrial ecosystems.

primary mechanism for $\mathrm{P}$ transport. Readily available $\mathrm{P}$ is more susceptible to transport; however all other forms are also vulnerable to losses.

Increased $\mathrm{P}$ concentrations in aquatic systems can stimulate biological productivity resulting in accelerated eutrophication of surface water. Phosphorus is the most limiting element in many aquatic systems and has been suggested as the major cause of water impairment in many regions in the USA (USEPA, 1996). Phosphorus

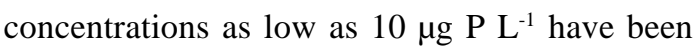
suggested to cause environmental problems associated with water quality (Pierzynski et al., 2005).

Confined animal operations and improper fertilization are considered to be the major sources of $\mathrm{P}$ entering water bodies. This phenomenon occurs primarily as a result of the intensification of agriculture, which has created imbalances between $\mathrm{P}$ inputs and outputs. Changes in soil $\mathrm{P}$ status in agricultural soils are largely dependent on agricultural practices. Nutrient management practices that can reduce $P$ inputs and yet maintain crop and animal production have been the major focus of many research programs in the USA. In $\mathrm{P}$-sensitive watersheds, where soil P levels were increased due to agricultural activities, $\mathrm{P}$ application is restricted by environmental regulatory agencies. Because soil test alone can not predict $\mathrm{P}$ transport, many other factors (i.e., rainfall, erosion potential) have been identified as indicators in different regions of the US as a tool to efficiently assess the risk of $P$ pollution. The $P$ index, for instance, was developed by 49 states in the USA as a nutrient management tool to predict the risk of $\mathrm{P}$ loss from agricultural fields (Sharpley et al., 2003; Snyder et al., 1999). The P index incorporates soil chemical and physical attributes and the characteristics of the watershed to address the site-specific potential for P losses. Based on the P-index concept, a site can be classified as very high, high, medium, or low risk of environmental $\mathrm{P}$ losses, and best management practices that can effectively minimize $\mathrm{P}$ transport can be selected for specific fields.

\section{Nutrient cycling on grazed pastures}

\subsection{Pathways of nutrient return}

Nutrient retention in cattle body tissue and nutrient export through beef or milk usually represents less than $30 \%$ of total nutrient ingested by cattle (Wilkinson \& Lowrey, 1973; Haynes and Williams, 1993). Therefore, most nutrients ingested by cattle returns to the pasture via excreta. 
The proportion of the nutrients not consumed returns via deposition of senescent plant material, the litter, on the soil. Thus, excreta and litter are the two major pathways of herbage nutrients return to the soil (Thomas, 1992).

Herbage nutrients (e.g., $\mathrm{N}$ and $\mathrm{P}$ ) represent a minor portion of total nutrients contained in a pasture ecosystem contrasting with soil organic matter (SOM) which is the major reservoir of pasture nutrients (Dubeux et al., 2004). The lesser proportion of herbage nutrients compared to other nutrient pools, however, does not reduce the importance of the herbage pool on pasture nutrient cycling. The importance of herbage nutrients in terms of nutrient supply increases because excreta and above-ground litter decompose faster than below ground biomass and SOM (Dubeux et al., 2006a). In fact, as management intensity increases (i.e., fertilizer use, stocking rate), it also increases the importance of herbage nutrient pool and it may supply even more nutrients for plant and microbial growth than SOM mineralization (Dubeux et al., 2004; Lira et al., 2006).

Nutrient return through excreta is not uniform. Cattle tend to congregate in small areas of the pasture, usually near shade, watering, and camping sites (Mathews et al., 1996; Haynes \& Williams, 1999). Thus, a greater proportion of excreta return occurs on these areas, reducing soil fertility in other pasture areas and increasing nutrient concentration at the resting sites (Dubeux et al., 2006b). Partitioning of nutrients between feces and urine also reduces the uniformity of nutrient return through excreta. Cattle grazing a given patch consume forage containing different nutrients; however, the return does not occur uniformly at a given site. Phosphorus, $\mathrm{Mg}$, and Ca return mainly in feces while $\mathrm{K}$ and $\mathrm{Na}$ return mainly via urine (Mathews et al., 1996). Because dung and urine events often do not occur at the same site, nutrient return is not uniform.

Litter is the other pathway of nutrient return on grazed pastures. Compared to excreta, nutrient return through litter is more uniform (Dubeux et al., 2006a). Litter decomposition with consequent nutrient supply for plant and microbial growth depends upon litter quality indicators, such as $\mathrm{C}: \mathrm{N}$, lignin:N, ADIN, and polyphenols (Myers et al., 1994; Dubeux et al., 2006c; Thomas and Asakawa, 1993). Litter of tropical grass pastures is hard-to- decompose due to its high $\mathrm{C}: \mathrm{N}$ ratio, lignin: $\mathrm{N}$, and acid detergent insoluble $\mathrm{N}$ (ADIN). As a result, nutrient immobilization occurs to a great extent in these areas, and it is considered one of the major causes of pasture decline (Robbins et al., 1989). In Brazil, most of the planted pastures are pure grass stands, usually from the Brachiaria genus, and to a lesser extent from the Panicum and Andropogon genera (Boddey et al., 2004). Therefore, low quality litter accumulation may be one of the causes of extensive pasture degradation in Brazil.

Nutrient bioavailability is greater in excreta than plant litter (Mathews et al., 1996), leading to a faster uptake by plants. The negative aspect of this is the nutrient loss, which is also greater when it returns via excreta, particularly $\mathrm{N}$ (Boddey et $a l .$, 2004). Because increasing stocking rate leads to a greater proportion of nutrient return via excreta compared to litter (Thomas, 1992), Boddey et al. (2004) concluded that pasture decline is hastened by increasing stocking rates without increase pasture primary productivity (i.e., increase in grazing pressure).

\subsection{Management options to improve nutrient} cycling efficiency

Grazing management exerts a major influence on herbage nutrient returns, altering the proportion of nutrients returned via excreta and litter (Thomas, 1992). Stocking method is one management option to improve nutrient distribution. Rotational stocking with short grazing periods may provide the high stocking density necessary to enhance uniformity of excretal return while reducing steep nutrient gradients near shade and watering sites (Peterson \& Gerrish, 1996). Dubeux (2005) compared dung distribution of heifers under two rotational stocking strategies (7$\mathrm{d}$ and 1-d of grazing period) with continuous stocking on Pensacola bahiagrass (Paspalum notatum Flügge) pastures. Rotational stocking with a 1-d grazing period promoted a more uniform dung distribution (Poisson distribution) compared to rotational stocking with 7-d grazing periods and continuous stocking, which followed a negative binomial distribution. Contrasting with this result, Mathews et al. (1994) suggested that stocking method may have little effect on shortterm (2-yr) soil nutrient distribution, especially

\footnotetext{
() 2007 Sociedade Brasileira de Zootecnia
} 
when grazing occurs during months when temperatures are high. These contrasting results may be due to the fact that Mathews et al. (1994) moved the water trough and the portable artificial shades along the fence line in both continuously and rotational stocked pastures, reducing potential nutrient concentration near those sites, while Dubeux (2005) did not move shade and watering points under continuous stocking, a practice more common among producers. Russelle (1997) suggested that moving shades and watering points improves nutrient distribution, but this may not be practical for more extensive systems.

Animal aspects that influence solar radiation tolerance may be considered in warm climates as tools to enhance nutrient distribution. Cattle breed and coat-color may interact with environmental conditions and thereby affect pasture utilization and nutrient redistribution patterns (Sollenberger et al., 2002). In this aspect, Brahman cattle spent less time under shade than non-Brahman cattle (Blackshaw \& Blackshaw, 1994) and Holstein cows with predominantly black coats spent $20 \mathrm{~min}$ $\mathrm{d}^{-1}$ more time under shade in Florida, USA compared to predominantly white-coated cows (Macoon, 1999). Because there is a correlation between time spent in a particular pasture area and the number of excretions (White et al., 2001), the more time the cattle spend under the shade, the greater is the nutrient concentration in that area (i.e., less uniformity of distribution).

Soil mesofauna may also improve nutrient cycling efficiency. Dung beetles (Scarabaeidae family) and earthworms (Lumbricidae family) increase the rate of mineralization, and reduce $\mathrm{NH}_{3}$ volatilization by incorporating feces into the soil, reducing denitrification through elimination of anaerobic zones within fecal deposits (Mathews et al., 1996; Mathews et al., 2001).

As mentioned in item $3.1, \mathrm{C}_{4}$ grasses produce low quality litter leading to nutrient immobilization and that is a potential problem for low-input/lowsoil fertility pastures. On the other hand, increasing stocking rate decreases deposited litter (Cantarutti et al., 2002) but increases nutrient losses via excreta (Boddey et al., 2004). A possible way to overcome these two situations and promote a more efficient nutrient cycling is by having a better quality litter. Mixed grass-legume pastures (Cantarutti et al., 2002) or pasture fertilization
(Dubeux et al., 2006d) are two options to improve litter quality. Economic aspects of pasture fertilization in tropical developing countries have not been favorable in the last years (Martha et al., 2004), therefore, the inclusion of a forage legume in pure grass pasture remains the best option to improve litter quality in these countries (Cantarutti et al., 2002, Dubeux et al., 2006a, Lira et al., 2006). Recent successful stories of grass-legume pastures in warm-climates include Desmodium ovalifolium (Cantarutti et al., 2002), Arachis pintoi (Valentim and Andrade, 2005a), Pueraria phaseoloides (Valentim \& Andrade, 2005b), and Calopogonium mucunoides (Zimmer \& Seiffert, 1983) in association with different Brachiaria species.

\section{Summary and Conclusions}

Rapid population growth will decrease the land designated to grassland forcing producers to intensify their agriculture systems. Intensification is associated with inputs to increase forage and animal production. Fertilizers and supplements are frequently used to achieve this goal. Nutrient cycling concepts can be used to maximize the utilization of nutrients already present in the grassland systems and consequently decrease the utilization of inputs that might be detrimental to water quality and the environment. There is a need to explore multidisciplinary forage research areas and generate scientifically sound data that will be used for future environmental policies that may be adopted by regulatory agencies.

\section{References}

ALLISON, F.E. Nitrogen transformation in soils. Soil and Crop Science Society of Florida, v.21, p.248-254, 1961

BLACKSHAW, J.K. \& BLACKSHAW, A.W. Heat stress in cattle and the effect of shade on production and behaviour: a review. Australian Journal of Experimentation Agriculture and Animal Husbandry, v.34, p.285-295, 1994.

BODDEY, R.M.R.; MACEDO, R.M.; TARRÉ, E. et al. Nitrogen cycling in Brachiaria pastures: the key to understanding the process of pasture decline. Agriculture, Ecosystem and Environment, v.103, p.389-403, 2004

BOSWELL, F.C.; MEISINGER, J.J.; CASE, N.L. Production, marketing, and use of nitrogen fertilizers In: O. P. ENGELSTAD (Ed.) Fertilizer Technology and Use. SSSA, Madison, WI. 1985. p. 229-292.

BURNS, J.C.; MCIVOR, J.G.; V.M.L., V. et al. Grazing systems for C4 grasslands: A global perspective, In L. E. MOSER, et al., (Ed.) Warm-season C4 grasses. ASA, CSSA, SSSA, Madison, WI, 2004. p. 309-354.

๑ 2007 Sociedade Brasileira de Zootecnia 
CANTARUTTI, R.B.; TARRÉ, R.; MACEDO, G. et al. Boddey. The effect of grazing intensity and the presence of a forage legume on nitrogen dynamics in Brachiaria pastures in the Atlantic forest region of the south of Bahia, Brazil. Nutrient Cycling Agroecosystens, v.64, p.257-271, 2002.

DUBEUX JR., J.C.B.; SANTOS, H.Q.; SOLLENBERGER, L.E. Ciclagem de nutrientes: perspectivas de aumento da sustentabilidade da pastagem manejada intensivamente. In: C.G.S. PEDREIRA, C.G.S.; MOURA, J.C.; FARIA V.P. (Eds). Fertilidade do solo para pastagens produtivas. Piracicaba, FEALQ, 2004, p. 357-400.

DUBEUX JR., J.C.B. Management strategies to improve nutrient cycling in grazed Pensacola bahiagrass pastures. Ph.D. dissertation, University of Florida, Gainesville. 2005. 204 p. Available on-line at http://etd.fcla.edu/UF/ UFE0011202/dubeux_j.pdf

DUBEUX JR., J.C.B.; LIRA, M.A.; SANTOS, M.V.F. et al. Fluxo de nutrientes em ecossistemas de pastagens: impactos no ambiente e na produtividade. In: C.G.S. PEDREIRA, J.C. MOURA, S.C. DA SILVA, V.P. FARIA (Eds.). As pastagens e o meio ambiente. Piracicaba, FEALQ, 2006a, p. 439-506. DUBEUX Jr., J.C.B.; STEWART JR., R.L.; SOLLENBERGER, L.E. et al. Spatial heterogeneity of herbage response to management intensity in continuously stocked Pensacola bahiagrass pastures. Agronomy Journal, v.98, p.1453-1459, 2006b

DUBEUX Jr., J.C.B.; SOLLENBERGER, L.E.; INTERRANTE, S.M. et al. Litter decomposition and mineralization in bahiagrass pastures managed at different intensities. Crop Science, v. 46, p.1305-1310, 2006c.

DUBEUX Jr., J.C.B.; SOLLENBERGER, L.E.; VENDRAMINI, J.M.B. et al.Litter mass, deposition rate, and chemical composition in bahiagrass pastures managed at different intensities. Crop Science, v.46, p.1299-1304, 2006d.

HADAS, A.; BAR-YOSEF, B.; DAVIDOV, S. et al. Effect of pelleting, temperature, and soil type on mineral nitrogen release form poultry and dairy manures. Soil Science Society of America Journal, v.47, p.1129-1133, 1983.

HAYNES, R.J.; WILLIAMS, P.H. Nutrient cycling and soil fertility in the grazed pasture ecosystem. Advances in Agronomy, v.49, p.119-199, 1993

HAYNES, R.J.; WILLIAMS, P.H. Influence of stock camping behaviour on the soil microbiological and biochemical properties of grazed pastoral soils. Biololgy of Fertility Soils, v.28, p. 253-258, 1999

JARVIS, S.C.; SHERWOOD, M.; STEENVOORDEN, J.H.A.M. Nitrogen losses from animal manures:from grazed pastures and from applied slurry. In: H. G. VAN DER MEER, et al. (Eds.) Animal manure on grassland and fodder crops. Fertilizer or waste? Developments in plant and soil sciences, v.30. Martinus Nijhoff, Dordrecht, The Netherlands. 1987, p. 195-212

KIRCHMANN, H. Losses, plant uptake and utilization of manure nitrogen during a production cycle. Acta Agriculture Scandinavia Supplementum, v. 24, p.1-77, 1985

KIRCHMANN, H. Carbon and nitrogen mineralization of fresh, aerobic, and anaerobic animal manures during incubation with soil. Sweden Journal of Agriculture Research, v.21, p.165173. 1991.

KIRCHMANN, H. Animal and municipal organic wastes and water quality, In: R. LAL \& B. A. STEWART (Eds.) Soil processes and water quality. CRC Press, Boca Raton, FL. P.163-222, 1994

LANYON, L.E. \& GRIFFITH, W.K. Nutrition and fertilizer use In: A.A. HANSON et al., (Eds.) Alfalfa and Alfalfa Improvement. ASA, CSSA, SSSA, Madison, WI. 1988, p.334-364. 1988

LAL, R. \& STEWART, B.A. Soil processes and water quality In: R. LALAND B. A. STEWART (Eds.) Soil processes and water quality. CRC Press, Boca Raton, FL. 1994, p.1-6.
LIRA, M.A.; SANTOS, M.V.F.; DUBEUX Jr., J.C.B. et al Sistemas de produção de forragem: alternativas para a sustenta-bilidade da produção. In: REUNIAO DA SOCIEDADE BRASILEIRA DE ZOOTECNIA, 2006, João Pessoa. Anais...João Pessoa: Sociedade Brasileira de Zootecnia, 2006. p.491-511.

MACOON, B. Forage and animal responses in pasturebased dairy production systems for lactating cows. $\mathrm{Ph} . \mathrm{D}$ dissertation, University of Florida, Gainesville, FL. 1999. p. 178 (Diss. Abstr. Int. 60B:5844).

MARTHA Jr., G.B.; VILELA, L.; BARIONI, L.G. et al. Manejo da adubação nitrogenada em pastagens In: C.G.S PEDREIRA, J.C. MOURA, S.C. DA SILVA, V.P. FARIA (Eds.). Fertilidade do solo para pastagens produtivas Luiz de Queiroz Agricultural Foundation, Piracicaba, SP Brazil. 2004. p.155-215.

MATHEWS, B.W.; SOLLENBERGER, L.E.; TRITSCHLER II, J.P. Grazing systems and spatial distribution of nutrients in pastures - soil considerations. In Joost, R.E.; Roberts, C.A. (Eds.). Nutrient cycling in forage systems. University of Missouri, Columbia, MO. 1996, p. 213-229.

MATHEWS, B.W.; SOLLENBERGER, L.E.; NAIR, V.D. et al. Impact of grazing management on soil nitrogen, phosphorus, potassium, and sulfur distribution. Journal of Environmental Quality, v.23, p.1006-1013,1994

MATHEWS, B.W.; CARPENTER, J.R.; SOLLENBERGER, L.E. et al. Macronutrient, soil organic carbon, and earthworm distribution in subtropical pastures on an andisol with and without long-term fertilization. Communication in Soil Science and Plant Analysis, v.32, p.209-230, 2001

MYERS, R.J.K.; PALM, C.A.; CUEVAS, E. et al. The synchronisation of nutrient mineralisation and plant nutrient demand. In: P. L. WOOMER AND M. J. SWIFT (Eds.) The biological management of tropical soil fertility. John Wiley and Sons, Chichester, UK. 1994, p. 81-116.

MUCHOVEJ, R.M.C. \& RECHCIGL, J.E. Impact of nitrogen fertilization of pastures and turfgrasses on water quality., In R. LAL \& B. A. STEWART (Eds.) Soil processes and water quality. CRC Press, Boca Raton, FL. 1994, p.91136.

OVERMAN, A.R.; WILKINSON, S.R.; EVERS, G.W. Yield response of bermudagrass and bahiagrass to applied nitrogen and overseeded clover. Agronomy Journal, v.84, p.9981001. 1992.

PEARSON, C.J. \& ISON, R.L. Agronomy of grassland systems. 2nd ed. Cambridge Univ. Press, New York. 1997, p.74-95.

PETERSON, L.A. \& KRUEGER, A.R. Variation in content of available $\mathrm{P}$ and $\mathrm{K}$ (Bray I) in soils samples from cropped $\mathrm{N}, \mathrm{P}, \mathrm{K}$ fertility experiment over 8 years. Communications in Soil and Plant Analysis, v.11, p.993-1004. 1980

PETERSON, P.R. \& GERRISH, J.R. Grazing systems and spatial distribution of nutrients in pastures: Livestock management considerations. In: R.E. JOOST AND C.A. ROBERTS (Ed.) Nutrient cycling in forage systems. PPI/ FAR, Columbia, MO. 1996, p.203-212.

PIERZYNSKI, G.M. \& LOGAN, T.J. Cropping patterns and their effects on phosphorus testing levels. Journal of Production Agriculture, v.6, p.513-520, 1993.

PIERZYNSKI, G.M.; SIMS, J.T.; VANCE, G.F. Soils and Environmental Quality, CRC Press, Boca Raton, FL. 2005.

Potash and Phosphate Institute. Soil test summary for phosphorus and potassium: Better Crops with Plant Food, 1987, p.12-13.

PRASAD, R.; POWER, J.F. Soil fertility management for sustainable agriculture. CRC Presss, Boca Raton, FL. 1997.

PRINE, G.M.; BURTON, G.W. The effect of nitrogen rate and clipping frequency upon the yield, protein content and certain morphological characteristics of Coastal bermudagrass 
[Cynodon dactylon (L.) Pers.]. Agronomy Journal, v.48, p.296-301, 1956.

ROBBINS, G.B.; BUSHELL, J.J.; MCKEON, G.M. Nitrogen immobilization in decomposing litter contributes to productivity decline in ageing pastures of green panic (Panicum maximum var. Trichoglume). Journal of Agriculture Science, v.113, p.401-406, 1989.

ROTZ, C.A.; SHARPLEY, A.N.; SATTER, L.D. et al. Production and feeding strategies for phosphorus management on dairy farms. Journal of Dairy Science, v.85, p.3142-3153, 2002.

RUSSELLE, M.P. Nutrient cycling in pasture. In: J. A. GOMIDE (Ed.) International Symposium on Animal Production under Grazing. UFV, Viçosa, MG. 1997, p. 235-266.

SCHEPERS, J.S. \& MOSIER, A.R. Accounting for nitrogen in nonequilibrium soil-crop systems., In: R. F. FOLLETT, et al. (Eds.) Managing Nitrogen for Groundwater Quality and Farm Profitability. SSSA, Madison, WI. 1991, p.125138.

SHARPLEY, A.N. \& HALVORSON, A.D. The management of soil phosphorus availability and its impact on surface water quality In: R. LAL AND B. A. STEWART (Eds.) Soil processes and water quality. CRC Press, Boca Raton, FL. 1994, p.7-91.

SHARPLEY, A.N.; CARTER, B.J.; WAGNER, S.J. et al. Sample. Impact of long-term swine and poultry manure applications on soil and water resources in eastern Oklahoma. Oklahoma State University. T-169, 1991

SHARPLEY, A.N.; WELD, J.L.; BEEGLE, D.B. et al. Development of phosphorus indices for nutrient management planning strategies in the United States. Journal of Soil and Water Conservation, v.58, p.137-152, 2003.

SHARPLEY, A.N.; DANIEL, T.C.; EDWARDS, D.R. Phosphorus movement in the landscape. Journal of Production Agriculture, v.6, p.492-500, 1993.

SMITH, R.A. \& ALEXANDER, R.B. Sources of nutrients in the nation's watersheds. Managing Nutrients and Pathogens from Animal Agriculture. Natural Resource, Agriculture, and Engineering Service, Ithaca, NY, p. 1321. 2000

SOLLENBERGER, L.E.; DUBEUX Jr., J.C.B.; SANTOS H.Q. et al. Nutrient cycling in tropical pasture ecosystems In: REUNIÃO ANUAL DA SOCIEDADE BRASILEIRA DE ZOOTECNIA, 2002. Recife. Anais...Recife: Sociedade Brasileira de Zootecnia, 2002.

SNYDER, C.S.; BRUULSEMA, T.W.; SHARPLEY, A.N. et al. Site-specific use of the environmental Phosphorus-Index concept. Site Specific Management Guidelines. SSMG1. Potash and Phosphate Institute. Norcross, GA. 1999.

TEITZEL, J.K. \& WILSON, R.J. Productive and stable pasture systems for cattle fattening in the humid tropics. 2. Field testing on naturally infertile site. Agricultural Systems, v. 36, p.267-277, 1991.

THOMAS, R.J. The role of the legume in the nitrogen cycle of productive and sustainable pastures. Grass and Forage Science, v.47, p.133-142, 1992.

THOMAS, R.J. \& ASAKAWA, N.M. Decomposition of leaf litter from tropical grasses and legumes. Soil Biology and Biochemistry, v.25, p.1351-1361, 1993

USEPA. Process Design Manual: Land Application of Sewage Sludge and Domestic Septage, Office of Research and Development. EPA/625/R-95/001. U.S. Government Printing Office, Washington, D.C. 1995. 28pp.

USEPA. Environmental indicators of water quality in the United States. U.S. Environmental Protection Agency, Office of Water (4503F). EPA 841-R-96-002. U.S. Government Printing Office, Washington, D.C., 1996. 25 pp.

VALENTIM, J.F.; ANDRADE, C.M.S. Forage peanut (Arachis pintoi): A high yielding and high quality tropical legume for sustainable cattle production systems in the western Brazilian Amazon. In: International Grasslands Congress, 20, 2005, Dublin. Proceedings...Dublin: International Grassland Society, 2005a, p. 328.

VALENTIM, J.F.; ANDRADE, C.M.S. Tropical kudzu (Pueraria phaseoloides): Successful adoption in sustainable cattle production systems in the western Brazilian Amazon. In: International Grasslands Congress, 20, 2005, Dublin. Proceedings... Dublin: International Grassland Society, 2005b, p. 328J.

VALK, H. \& HOBBELINK, M.E.J. Supplementation of dairy grazing cows to reduce environmental pollution. General Meeting of the European Grassland Federation, 14th, 8-11 June, Lahti, Finland. European Grassland Federation. 1992, p. 400-405.

VAN VUUREN, A.M. \& MEIJS, J.A.C. Effects of herbage composition and supplement feeding on the excretion of nitrogen in dung and urine by grazing dairy cows. In: H.G. VAN DER MEER, (Ed.) Animal manure on grassland and fodder crops. Fertilizer or waste? Martinus Nijhoff,, Dordrecht, The Netherland. 1987. p.17-25.

VICENTE-CHANDLER, J.; ABRUNA, F.; CARO-COSTAS, R. et al. Intensive Grassland management in the humid tropics of Puerto Rico. Univeristy of Puerto Rico Agriculture and Experiment Station, Mayaguez. Bull. 233. 1974.

VIEIRA, A.C.; CASTRO, F.G.F.; VENDRAMINI, J.M.B. et $a l$. Dry matter yield and nutritive value of Cynodon dactylon cv. Florakirk at different ages of regrowth. Scientia Agricola, v. 56, p.1185-1191, 1999.

WHITE, S.L.; SHEFFIELD, R.E.; WASHBURN, S.P. et al. Spatial and time distribution of dairy cattle excreta in an intensive pasture systems. Journal of Environmental Quality, v.30, p.2180-2187, 2001.

WHITEHEAD, D.C. Nutrient elements in grassland: Soilplant-animal relationships $\mathrm{CAB}$ Int., Wallingford, Oxon, UK. 2000

WILKINSON, S.R.; LOWREY, R.W. Cycling of mineral nutrients in pasture ecosystem, In: BUTLER, G.W.; BAILEY, R.W. (Eds.), Chemistry and Biochemistry of Herbage, vol. 2. Academic Press, New York, NY. 1973, p. 247-315.

Word Resource Institute. World resources 2000-2001 database, In: WORLD RESOURCE INSTITUTE (Ed.), Washington, DC. 2001

WU, Z.; SATTER, L.D.; SOJA, R. Milk production, reproductive performance, and fecal excretion of phosphorus by dairy cows fed three amounts of phosphorus. Journal of Dairy Science, v.83, p.1028-1041, 2000.

ZIMMER, A.H.; SEIFFERT, N.F. Consorciação de Brachiaria decumbens cv. Basilisk com Calopogonium mucunoides. EMBRAPA/CNPGC. Comunicado Técnico, n.18, 1983 